\title{
A Tree Walks through the Forest: Milkwoods and other Botanical Witnesses
}

\author{
William Ellis \\ University of the Western Cape \\ wellis@uwc.ac.za
}

Our tour group stopped at the large circular raised step of a curated memorial located on the traffic island in the middle of Loop Street, which is situated in downtown Cape Town just a short distance from the South African Parliament. We read the inscription, which indicated that a tree once stood here, and that this tree marked the place where slaves were once sold. Our guide directed our attention to a watercolor painting nearby that shows a scene from the early Dutch colony, suggesting a bustling market-a slave market. My father's great-greatgrandmother was a Maasbieker (Afrikaans corruption of the word Mozambican) slave, and I wonder, had she passed through this market? My critical reflections about the tree drove me to new thoughts, specifically about this tree and its exact identity. I could with greater certainty make more claims about the identity of this tree than I could about the name, language, and culture of this great Maasbieker woman who would lead down to me. The tree was a stone pine and these were brought in to replace the retreating milkwood forests. The tears of slaves, their spit, sweat, effluvia, and blood at the base of this tree means that this tree holds literally holds parts of the people, their lives, their stories, their atoms and is in fact now an ancestor, connected because it is imbued with the essences of my forebears. If I could eat the fruits or leaves of this tree, I would have them with me.

My research explores the connections between humans and the world at large, especially the intimacies and connections we form with plants knowingly or 
unknowingly. Like Jane Bennett (2009) whose work seeks a vitalism in the intermingling of the mineral, vegetal, and animal, I seek it here in the trees and the people. In doing so, I draw insights from Manuel Delanda's (2006) reworking of "assemblage" and Bruno Latour's (2005) network of "actants" to explore how these rhizomatic connections (Deleuze \& Guattari, 2010) and are not just a becoming forward but also a historical becoming as we (re)intergrate with the vegetal. In recognition of the agency of plants, their complex relationship with humans, the intimacies they cultivate with us, their cryptic silence, and refusal to do more, my work asks how we are admitting a kinship. In particular, my work explores these questions in learning from the milkwood tree.

Trees such as milkwoods became scarce in the early Dutch colony as settlers cleared the land for farming and establishing settlements. The most numerous tree was the milkwood, also known by its botanical name as Sideroxylon inerne, which literally means iron-wood. Colonial settlers prized milkwood trees as a hard wood great for shipbuilding, tool-making, and architectural uses. As a result, the great milkwood forests that the Dutch and British encountered when they first landed on these shores have been almost completely decimated in what can be called a vegetal genocide that has left behind only scattered specimens.

At least four of these trees have been venerated as national monuments, standing as lone reminders of the great natural parliament of trees that once existed and of the forced moments of subjugation enacted under colonialism. The Fingo Tree, a giant milkwood near Peddie in the Eastern Cape of South Africa, for example, memorializes past colonial histories of when Mfingo peoples were compelled, in 1835, to confess their faith to Christianity and pledge their obedience to the British king. The Post Office Tree in Mossel Bay also evokes critical reflection on the colonial taking of South African lands as the milkwood once served as a site for colonial explorers to share communications between sailors such as reports of the death of the pirate Dias (Pakenham, 2007). At the same time, a massive lone milkwood specimen near Bredasdorp was recently granted monument status due to its impressive size (Platbos, 2018). However, alone and without its kin, this tree stands as evidence of another colonial massacre in the slaughter of trees. In still another example, in Woodstock stands the over five-hundred-year-old Treaty Tree where the Dutch handed over their colony to the British and where runaway slaves were hanged. I imagine the excrement of the executed and how their urine and feces at the roots nourished this tree. Thus, the essences of the dead, the unnamed colonial dead, are still with us in the flesh of a tree that is a witness to their deaths and a site for their remains. 
I know of another specimen that tells an interesting story of the natural world and of ours. In the curated forest at Platbos Indigenous Forest near Hermanus, there is a milkwood tree thought to be at least a one thousand years old. The milkwoods at Platbos are all genetically the same plant (Platbos, 2018). The custodians of this forest, Francois and Mellissa Krige, write that the milkwoods collapse and that all new "trees" grow from the trunk of this same tree. It is as if the tree is walking through the forest very slowly over thousands of years(ibid), generating a slow creep of trees and an interlinking of roots that, I contend, suggests a rhizomatic connection spanning vast amounts of space but also time. It is these connections across space and time and to a people that I seek to understand and demonstrate in my research on milkwoods. I ask how this vast milkwood forest, which once covered the coastline from the Cape into the Eastern Cape, was and is part of a vast rhizomatic, vegeto-neural network that discursively, symbolically, and epigenetically retains events and evidence. I suggest ways of understanding these milkwood forests as one massive organ that witnessed the haggling for slaves, the execution of captives, and the conviction and subjugation of a people, and, at the same time, observed those very settlers who committed these acts of violence as they sat in churches protected by milkwood beams supporting the thatch or tiled roofs of their chapels. These trees are the true monument to Khoi and San because it is under the branches of these trees that they worked and played. It is here that they left their essences and it is here under these trees that they shared their lives and lived. It would seem fitting that for these reasons the milkwoods should be the authentic monuments to Khoi peoples and that the trees are really a marker of curated "Khoisan outside." The "Khoisan outside" frees Indigenous Peoples and the slaves from the glass box of the museum and takes them to where their lives were really lived, outside.

\section{Acknowledgements}

I would like to acknowledge the group of researchers at the University of the Western Cape known as the "plant gang" for always being willing to listen and share ideas about plants.

\section{References}

Bennett, J. (2009). Vibrant matter: A political ecology of things. Durham, NC: Duke University Press.

DeLanda, M. (2006). A new philosophy of society: Assemblage theory and social complexity. London: Continuum Books.

Deleuze, G., \& Guattari, F. (2010) Nomadology: The war machine. Seattle, WA: 
Wormwood Distribution.

Latour, B. (2005). Reassembling the social: An introduction to actor-network-theory. London: Oxford University Press.

Pakenham, T. (2007). In search of remarkable trees: On safari in Southern Africa. London: Weidenfeld and Nicolson.

www.platbos.co.za/african_tree_essence_milkwood.html

\section{Author Bio}

William Ellis is a lecturer in Anthropology at the University of the Western Cape. He maintains strong interests in KhoiSan studies, indigeneity and is passionate about researching the human plant interface and the ethnography of the other than human. At present he is working on several projects in the Northern Cape, South Africa that aims to examine knowledge connections and plant ontologies. 